\title{
The Effect of E-Learning on Learning and Interest in School Attendance among Elementary School Students
}

Seyedehsahar Shafieiosgouei

Payamme Noir University, Iran shafiei@pnu.ac.ir.edu

\section{Robab Hassantofighi}

Azad University of Tabriz, Iran htofighi33@gmail.com
Nava Nourdad

University of Tabriz, Iran nourdad@tabrizu.ac.ir

Seyyedreza Shafieioskouei

Azad University of Iran

s.re.shafiee@gmail.com

\begin{abstract}
The technological advances of the $21^{\text {st }}$ century have impacted all spheres of life, including education. The world of books and pens is being replaced by computers at young ages. The present study aimed at investigating the effect of technology on Iranian elementary school students' learning and interest in school attendance. The participants were 47 sixth grade students selected from two schools with and without technological support. The results of the study revealed a higher level of interest in school attendance in the group provided with technology. Consequently this study may have beneficial pedagogical implications for learners, teachers, and curriculum developers.
\end{abstract}

KEYWORDS: E-Learning school, interest in school attendance, technology

\section{Introduction}

As the technology in the $21^{\text {st }}$ century continues to evolve rapidly, it is unknown whether technological innovations have had a positive impact on our daily lives. One such area 
of interest and evolving research is in the educational arena. The impact of technology on education has always been under scrutiny. The current research focused on the effect of E-Learning which includes multimedia, software, computers, internet, etc on interest in school attendance and learning of elementary school students. Secondly, one of the goals of this research was to elucidate the ways in which technology can impact education, particularly at young ages in Iran's educational system. This is a topic of extreme importance because technology has not been fully integrated in the primary educational system in Iran, especially at younger ages. Thus, the impact of this research and information gained from it, can contribute to the development of better educators, well rounded students, and therefore a healthy and joyful learning environment.

The current research further focused on addressing whether educational systems can use technology to optimize interest in school attendance. Keeping these issues in mind, it is necessary to mention that in developing countries such as Iran, using technology at early ages is not supported or practiced. However, the current research investigates the potentially positive contributions of technology on interest in school attendance and learning at young ages in Iran.

One of the concerns in today's world is that the new generation lacks creativity because of access to abundant technology. The interplay that exists between technology, learning, and education is inseparable in the $21^{\text {st }}$ century. It is critical to understand the impact of technology in education and more importantly interest in education, which leads to interest in school attendance, and subsequently to learning and creativity. Children can help teach one another about the use of technology in school as well as learn the lessons taught. Uneducated parents and guardians no longer need to worry about teaching their kids or helping them with homework because children learn to self-teach with the use of the technology. In addition, kids are able to teach the use of new technology to their parents which creates a warm learning atmosphere where parents and children can learn from one another and have fun while doing it. Thus according to Alismail et al., (2015) technology such as E-Learning is a powerful tool, which allows students to access information and knowledge by themselves, leading to independent learning. Teachers have the responsibility to guide students as they research and obtain information in order to further develop that skills. Subsequently, without even knowing it students "learn how to learn" and develop their own learning strategies that can last a life time.

On the other hand there are families that not only do not have access to technology at home, they do not agree with the use of technology in education. This research relieves their concern because it demonstrates that presence of technology at home is 
not necessary. Educational systems that offer technology allow the learner to rely on him or herself to learn and eliminate the need to rely heavily on teachers, therefore becoming independent learners at a young age.

The idea that technology can facilitate knowledge in classrooms has been investigated in the past. According to Bork (1985), computers are viewed as giving influential effect on teaching and learning process. In addition, with computers in classroom, schools become more student-centered and that more individualized learning will take place. However, attention to interest in school attendance has not been attended in the past studies. The novelty of the current research lies in its focus on interest in school attendance. Further, it addresses the hesitancy of educational practitioners and educational system in the correct use of technology and its impact on young learners' literacy.

Previous studies reflect that teaching methods in advanced educational environments are demonstrating a more positive outlook to the world of E-Learning (Shafiei, et al. 2014). Parents and practitioners of educational systems can foster interest and provide the environment needed for this learning. However, many parents prevent youth from the use of technology at very young ages, due to the fear that technology may be used for non-educational activities and waste learning time.

The goal of educators at all levels is to use different strategies to teach complex concepts. In today's world, technology has become a part of daily life and as such learning in the $21^{\text {st }}$ century must integrate E-learning in order to reach out to the learners. Therefore, the old strategies of teaching that relied heavily on books must be replaced by the updated teaching strategies that rely on the use of E-learning which enhance learner interest in education. As stated by Jacobsen et al., (2001) many technological tools can support different skills such as problem solving, critical thinking, and collaborative learning. E-learning tool such as portfolios, Wiki, Google, Digital Storytelling, ePortfolios, Blog, etc., support these skills. These tools offer students the option of working in collaborative groups, which may increase student motivation and develop critical thinking. Multimedia tools such as E-learning promote deeper understanding to complete class activities.

To introduce the difference between E-learning and non-E learning schools in Iran the below descriptions are provided.

Non-E learning school: Learning is solely based on the teacher's ability to teach and the pre-determined books used. This takes away the ability of the student for critical thinking and creativity. Furthermore, there is no emphasis on hands on or practical 
approach to learning in this type of schools. Learning is therefore a dictation that is enforced by books, teachers, guardians, and curriculum developers.

E-Learning schools: The learning in these schools relies on the combination of teacher's directions and computer based lesson plans. Once the lesson plan has been given, students prepare PowerPoint slides based on the lesson taught on that day. The following day, the power point is presented to the class. This method reinforces the material that was learned. It further fosters creativity and imagination in learning. It reduces parents and guardian's anxiety about the misuse of technology based devises. It further encourages guardians to be involved with the use of technology based devises by allowing them to monitor its use in education as well as in hobbies.

There is often a feeling amongst educators that it is increasingly more difficult to get students more interested in education. Hence, there has always been an interest in using updated technology as a tool in teaching, especially amongst uninterested learners. As we look at the evolution of technology in early days of education, one can see that technology evolves at lightning speed. The era of ink and paper has been rapidly replaced by the era of multi-media and computers. Yet there has always been a question about the role of technology in education and whether technology has revolutionized education.

In societies like Iran, there are still some guardians who concern children's use of computers for purposes other than school education. In the same vein, there are still many elementary school children that dread going to school and often are forced by their parents to attend classes. In E-learning school like ALAVI elementary school which was used in the current research, parents monitor students' use of E-learning tools to study, do homework, and prepare PowerPoint presentations as part of their school curriculum. On the other hand, in non-E learning schools, parents and school educators mostly prevented student's use of E-learning tools either at home or at school. Thus, the purpose of the study was to assess whether technology in education, has an impact on learning and interest in school attendance. In this regard the following questions were posed:

1. Does E-Learning improve learning at elementary school?

2. Does E-Learning improve interest in school attendance at elementary school? Based on the previous studies, theoretical background of the study and considering above-mentioned research questions the following hypothesis were presented:

H1. E-Learning improves learning at elementary school.

H2. E-Learning improves interest in school attendance at elementary school. 


\section{REVIEW OF THE LITERATURE}

\section{Theoretical Background}

Today there is a common interest amongst educators at all levels to raise school achievements with integration of technology. The core standards in curriculums increasingly emphasize the use of technology as part of education and as a result there will likely be even more emphasis on integration of technology in education (Cristen 2009). As an example, technology can be used as a tool for establishing meaningful projects to engage students in critical thinking and problem solving. Furthermore, technology can be used to restructure and redesign the classroom to produce an environment that promotes the development of higher-order thinking skills (Kurt 2010).

However, there has always been reluctance amongst teachers and parents regarding the impact of technology in learning in early education. According to DePasquale et al (2003), programmed instruction and electronic worksheets have caused teachers to fear that children will miss out on key experiences that support their development if computer technology infiltrates teaching.

In another example, the use of internet and the importance of integration of internet based technology into classrooms are discussed in many studies. According to a case study done by Ebrecht et al (2015), the question is no longer should technology be integrated into literacy instruction, but how literacy instruction can be enhanced with technology (Hansen 2008). They further mention that in this digital age it is the responsibility of the teachers to guide and coach student's use of technology by providing learning opportunities that utilize technology.

But before technology is embedded in the very core of education, it is imperative to understand its purpose and role. Technology is a tool and therefore should be selected based on the individual needs of each learner. For example, technology can be an effective tool for English language learners and can enhance the participation of children with disabilities. Children in elementary schools should begin to use technological tools as a part of their academic program. Similarly, to enhance learning, teachers should model the use of technology in support of the curriculum so that children can see the appropriate use of technology (DePasquale et al. 2003).

As stated by (Kanuka et al.2007) previous studies have found that students who used multimedia tools in teaching have higher-level thinking skills than in comparison with traditional teaching methods.In addition, the power of E-learning tools is in their ability to allow students to evaluate their peers' work when using it. This strategy 
helps students to develop critical thinking skills. Incorporating E-learning tools in education gives students the opportunity to enhance academic and social skills as they communicate and share information, arrange their ideas, and communicate opinions while preparing a project or conducting research (Alismail et al. 2015).

According to Jacobsen (2001) technological tools in teaching gives students the opportunity to engage in the real world, allowing them to develop creativity and innovation skills. There are many outlets in the virtual world from which educators can guide students to see the real world through their own online experience. Examples include video game technologies, role-play in online simulated learning environments, and videos can be effective means to observe real life problems and come up with solutions. As such, using multimedia tools is an excellent way to increase student performance and motivation to learn by encouraging discussion, collaboration, problem solving, and innovation, promoting cognitive processes and constructing knowledge (Mueller 2006).

\section{Empirical Background}

To portray the contribution of technology in education, it is important to reference prior publications and research conducted in this area. As an example, in 2009, Van Meter Community School in Iowa adopted a one-to-one laptop initiative in grades 6-12. Through this educational transformation, Van Meter has become a place where students can find their passion. They are using technology to interact and exchange ideas, research independently, adapt to new situations, and take ownership over their own learning (Miller 2011).

In another study, effects of E-learning and communication technologies on students math and science achievement were conducted with 4,996 students in Turkey. The data was obtained from the results of The Program for International Student Assessment (PISA), a standardized test given to 9th grade students. The study results indicated that students' exposure to Information and communication technology at home and school had a positive impact on their math and science achievement scores. Students' who spent a lot of time using technology were shown to have increased science knowledge. They also performed better on math skills. Thus, information and communication technology has a positive effect on student learning and should be included in classroom instruction (Bulut \& Delen, 2011). Yet in another study, DePasquale et al (2003) through their work, demonstrated that using digital imagery such as photography and videography, students not only learn to use technology, they use it to record lessons and review them to further solidify their understanding of the 
lessons. The same group show how elementary school students use digital imagery for learning in class and later uploading their images on a classroom website which further teachers students the art of web design in addition to reinforcing the lessons they were taught.

Lastly, as a final example, use of blogs as a technological tool in education has been demonstrated in multiple studies. According to Solomon et al (2007), weblogs, or more commonly called "blogs," have emerged as a powerful instructional tool that can directly support literacy and technology skills while utilizing a cooperative approach to instruction. Simply defined, blogs are websites that allow authors to publish content instantly to the Internet through the use of text, images, and/or links to other related information found on the Internet (Solomon et al, 2007). Blogging enhances and supports meaningful communication by providing a web platform that provides users an easy way to create, update, and publish content. The readers of the blog then have the opportunity to respond to the author, thus providing an interactive conversation between the author and the reader (Howland et al, 2012).

Considering all the studies conducted on the subject of technology and its impact in education, the impact of technology specifically E-learning on elementary school students' learning and interest in school attendance in Iran has never been studied. Thus the objective of this study was not only to address these issues, but also help alleviate the anxiety felt by parents or guardians regarding the negative effect of technology in school attendance and learning.

\section{Methodology}

\section{Participants}

As it is demonstrated in Table 1, the participants of the study were selected from elementary school students and their parents from two schools in the same county. One of the schools was an E-learning and the other school was a non-E- learning school. Out of the 30 students in the E-learning class, 4 students did not wish to participate in the current study as such 26 were selected to participate in this study. Similarly 21 students were selected from the non-E-learning school. Students participating in this study were approved to be of the same level according to their teachers. Out of the total 47 selected students, 26 (55.3\%) were girls and 21 (44.7\%) were boys. Out of the 26 girls, half were in E-learning school, and the other half were in non-E learning school. Similarly, out of 21 boys, 10 were in E-learning schools and 11 in non-E learning schools. 
Table1: The Frequency of Male and Female Distribution

\begin{tabular}{ccccc}
\hline & Frequency & Percent & Valid Percent & Cumulative Percent \\
\hline Boys & 21 & 44.7 & 44.7 & 44.7 \\
\cline { 2 - 5 } Girls & 26 & 55.3 & 55.3 & 100.0 \\
\hline Total & 47 & 100.0 & 100.0 & \\
\hline
\end{tabular}

\section{Data collection instruments}

The current research utilized a questionnaire addressed to parents and school guardians. It contained 10 items based on a 5-point Likert's scale (strongly disagree, disagree, unsure, strongly agree, and agree). The first section of the questionnaire included the students' gender, age, and name of the school. The second section included the opinion of parents or guardians on the impact of E-learning such as any technological devises on each student's interest in school attendance. The validity of the questionnaire was confirmed by three educational experts: a TEFL university professor, an instructor in Education and a Lecturer in TEFL. In addition, the reliability was measured using Cronbach's alpha in a group with a coefficient of 0.83 which indicates the internal consistency of the questionnaire and the current research.

In addition, to assess the amount of learning objectively, tests were conducted in these schools that relied on a 20-point nation-wide scale in different subject matters at the end of the semester. The scores in these tests, provided by the teachers in each class were utilized in our research.

\section{Data collection procedures}

To initiate the current research, the researcher had to first obtain consent from the head of the ministry of education as the participants of the study were selected from elementary school students and their parents. Study participants were assured and informed that their responses to the questionnaires would remain anonymous; and that their answers would be used for the purposes of current research and improvement of learning in educational environments. Throughout the study, the researcher had to measure both the degree of learning and the level of interest in attendance. To do this, a questionnaire was distributed among all parents via each student, at the end of the semester. The questionnaire was to be filled out by each parent to assess the level of interest in school attendance. Next, to assess the level of learning, grades from 
a nation-wide standardized test which was numerical based and validated by the ministry of education was used. This test was conducted at the end of the semester of each year and the researcher used the grades collected for both E-learning and non-E learning schools.

It is important to mention that, the educational system in Iran is organized in to a 6-3-3 model, which corresponds to 6 levels in Elementary school, 3 in Middle school, and 3 in High school. Since school performance in Elementary education is descriptive i.e. (based on Excellent, Very good, Good, Acceptable, un-acceptable) as oppose to numerical based grading in middle and high school. Thus, to assess readiness to promote to middle school and subsequently to high school, a nation-wide test that is standardized is conducted. To accomplish the above plan, the questionnaires targeted two kinds of school. One school used E-learning tools that included technological devices such as computers and software tools monitored by the teachers, as well as textbooks. While the other focused primarily on non-E-learning methods such as text books and other traditional methods based on teacher-centered approaches.

\section{Research Design}

A survey based research design was selected for the present investigation. The data analysis was a quantitative-causal-comparative (Ex-post Facto), that was used to compare the level of interest in school attendance and the amount of learning in educational environment. Since the researcher tried to get as much information as possible about the degree of interests of learners and students, an opinion-based questionnaire was used for this purpose.

Table 2: Research Variables

\begin{tabular}{ccc} 
Variables & Type of variable & Scale of variable \\
\hline Type of school & Independent & Nominal \\
\hline Learning & Dependent & Scale \\
\hline Interest in School Attendance & Dependent & Scale \\
\hline
\end{tabular}

\section{FINDINGS AND DISCUSSION}

As illustrated in table 3, in the E-learning class, 26 were selected. Similarly, 21 students were selected from the non-E-learning school. 
Table 3 : The Frequency of E-learning and Non-E-Learning school participants

\begin{tabular}{ccccc}
\hline & Frequency & Percent & Valid Percent & $\begin{array}{c}\text { Cumulative } \\
\text { Percent }\end{array}$ \\
\hline Non-E learning & 21 & 44.7 & 44.7 & 44.7 \\
\hline E-Learning & 26 & 55.3 & 55.3 & 100.0 \\
\hline Total & 47 & 100.0 & 100.0 & \\
\hline
\end{tabular}

Based on the above table, $44.7 \%$ of the participants were from non-E learning schools and $55.3 \%$ from E-learning schools.

As indicated in table 4, normal distribution of scores for the Kolmogorov-Smirnov test was used.

Table 4: The One-Sample Kolmogorov-Smirnov Test

\begin{tabular}{cccc}
\hline & $\mathrm{N}$ & $\begin{array}{c}\text { Kolmogorov- } \\
\text { Smirnov Z }\end{array}$ & $\begin{array}{c}\text { Asymp+ Sig } \\
\text { (2-tailed) }\end{array}$ \\
\hline Learning & 47 & .72 & .67 \\
\hline $\begin{array}{c}\text { Interest in attending } \\
\text { educational environment }\end{array}$ & 47 & .88 & .41 \\
\hline
\end{tabular}

Based on Table 4, due to significant levels obtained; it was concluded that the variables of interest in attending educational environments and learning are normally distributed $(\mathrm{P}<0.05)$.

To answer the first research question which inquired about the impact of E-learning and Non-E-leaning schools on learning, the overall learning scores of the control and experimental groups were compared using an independent $t$-test demonstrated in Table 5 below.

Table 5: The independent Samples Test for Amount of Learning

\begin{tabular}{|c|c|c|c|c|c|c|c|}
\hline & \multirow{2}{*}{ School } & \multirow{2}{*}{$\mathrm{N}$} & \multirow{2}{*}{ Mean } & \multirow{2}{*}{ Std. Deviation } & \multicolumn{3}{|c|}{ t-test for Equality of Means } \\
\hline & & & & & $\mathrm{T}$ & $\mathrm{df}$ & Sig. (2-tailed) \\
\hline \multirow{2}{*}{ Learning } & $\begin{array}{l}\text { Non-E } \\
\text { learning }\end{array}$ & 21 & 3.74 & .55 & \multirow{2}{*}{-2.92} & \multirow{2}{*}{45} & \multirow{2}{*}{.005} \\
\hline & E-Learning & 26 & 4.14 & .41 & & & \\
\hline
\end{tabular}


The mean scores were calculated on a 5 point scale, with a mean score of 4.14 in E-learning schools and 3.73 in the non-E learning schools. Given that there was no statically significant difference in the scores, the null hypothesis was accepted. It was, therefore, concluded that the amount of learning in schools with and without the support of E-Learning support is almost the same. To answer the second research question another independent $\mathrm{t}$-test was used as the results of which is presented in Table 6.

Table 6: Independent Samples $t$-Test for Degree of Interest in school attendance

\begin{tabular}{|c|c|c|c|c|c|c|c|}
\hline & \multirow[b]{2}{*}{ School } & \multirow[b]{2}{*}{$\mathrm{N}$} & \multirow[b]{2}{*}{ Mean } & \multirow{2}{*}{$\begin{array}{c}\text { Std. } \\
\text { Deviation }\end{array}$} & \multicolumn{3}{|c|}{$\mathrm{t}$-test for Equality of Means } \\
\hline & & & & & $t$ & Df & $\underset{\text { (2-tailed) }}{\text { Sig. }}$ \\
\hline \multirow{2}{*}{$\begin{array}{c}\text { Interest in school } \\
\text { attendance }\end{array}$} & $\begin{array}{l}\text { Non E } \\
\text { Learning }\end{array}$ & 21 & 3.79 & .64 & \multirow{2}{*}{-2.44} & \multirow{2}{*}{45} & \multirow{2}{*}{.019 } \\
\hline & E-learning & 26 & 4.26 & .69 & & & \\
\hline
\end{tabular}

As illustrated in the table 6, the mean of interest in school attendance was 4.26 in E-learning schools and 3.79 in non-E learning schools. According to the results of t-test, student's interest in school attendance was significantly higher in E-learning schools compared to the non-E learning schools based on the significant $\mathrm{p}$ value of $<0.05$. Thus the second null hypothesis indicating that the degree of interest in school attendance at E-learning and non-E learning school is the same was rejected. Therefore, it was inferred that E-learning improves interest in school attendance of elementary school students.

\section{DISCUSSION}

The current study investigated the effect of E-learning on the amount of learning and interest in school attendance among elementary school students. The results proved the positive role of technology in school attendance interest. However, it did not affect the amount of learning. The findings of this study were in line with the findings of Bork (1985) and Cristen (2009), that technology plays an integral role in learning and education as a whole. However, the idea of improvement in school attendance by providing technology in schools is not scrutinized in the past investigations.

Also the above findings were in contrast with the findings of Nazarlou (2013), which indicated that E-learning has multiple negative implications in physical, mental and 
psychosocial well-being of learners. Not only does E-learning cause physical damage to multiple organs including the eye as a consequence of radiation, it also contributes to many musculoskeletal complains including carpel tunnel syndrome, neck and back pain. In regards to the impact of E-learning on mental and psychosocial aspect of learners, Nazarlou (2013) indicated that isolation of learners forces a less face to face interaction with the outside world thus negatively influences the ability of learners' interpersonal skills.

It has been observed that education that relies on direct teaching of lesson from books has limited benefit. This method of teaching only helps commit lessons to short term memory and as such is easily forgotten after examination, lending to stressful school experience for children and parents. On the other hand, when learning takes place with interest, it is committed to long term memory and foster creativity. In addition, the exam night stress is replaced with eagerness to demonstrate learned knowledge. With regard to the impact of technology in learning, the current study concluded that there was no significant contribution of technology in learning. However, the researchers highlighted that technology has a positive impact in school attendance. Taking into consideration the pros and the cons of technology in education, the researchers was in line with Chomsky (2014), that "As far as technology itself and education is concerned, technology is basically neutral. It's like a hammer. The hammer doesn't care whether you use it to build a house or whether on torture, using it to crush somebody's skull, the hammer can do either".

To illustrate the above mentioned concept, the diagram 1 below was designed. As demonstrated in the below diagram, the interconnectedness and an intricate cycle exists between society which consists of (parents, teachers to support and curriculum developers), interest in school attendance, young learners and technology e.g. (software and computer based devises) with successful learning at its core. Therefore, for successful learning a balanced interaction between all variables of the cycle is necessary. Thus, in the absence of interest in school attendance, there can never be successful learning. 


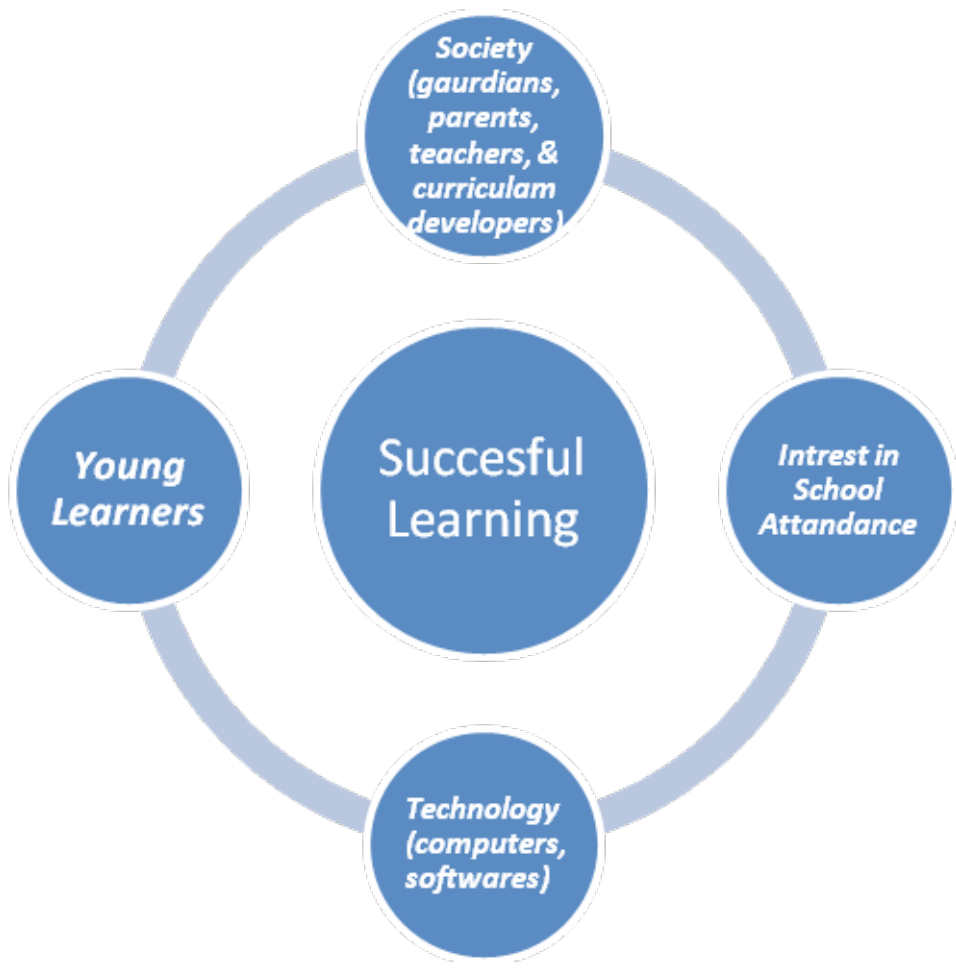

Diagram 1: The intricate cycle of successful learning

Accordingly, this study demonstrated a novel idea that having technology available in schools, improvement in school attendance can be accomplished. Consequently, it can be inferred that by improving school attendance there may be more opportunities to learn. As an example, in societies like Iran, there are still guardians that have daily struggles with students' school attendance. Students, especially young learners, are forced to attend school by their parents. As such, they develop a negative attitude towards school and educational materials such as textbooks. On many occasion it has been common to see students destroy their text books after the school year, and not show any interest in preserving educational materials.

However, when curriculum designers integrate technology in daily educational materials, an automatic interest is generated in students that encourage school attendance. In addition, parents and guardians have a peace of mind, knowing that technology is utilized for educational purpose under direct teacher supervision. Therefore, having technology in schools is an automatic incentive for technology savvy and technology loving young minds to attend and participate in educational 
activities. This in turn lends to higher motivation and also secondary learning through participation.

Table 1. Frequency of Male and Female Distribution

\begin{tabular}{ccccc}
\hline & Frequency & Percent & Valid Percent & $\begin{array}{c}\text { Cumulative } \\
\text { Percent }\end{array}$ \\
\hline Boys & 21 & 44.7 & 44.7 & 44.7 \\
\hline Girls & 26 & 55.3 & 55.3 & 100.0 \\
\hline Total & 47 & 100.0 & 100.0 & \\
\hline
\end{tabular}

Table 2, Research Variables

\begin{tabular}{ccc} 
Variables & Type of variable & Scale of variable \\
\hline Type of school & Independent & Nominal \\
\hline Learning & Dependent & Scale \\
\hline Interest in School Attendance & Dependent & Scale \\
\hline
\end{tabular}

Table 3. Frequency of E-learning and Non-E-Learning school participants

\begin{tabular}{ccccc}
\hline & Frequency & Percent & Valid Percent & $\begin{array}{c}\text { Cumulative } \\
\text { Percent }\end{array}$ \\
\hline Non-E learning & 21 & 44.7 & 44.7 & 44.7 \\
\hline E-Learning & 26 & 55.3 & 55.3 & 100.0 \\
\hline Total & 47 & 100.0 & 100.0 & \\
\hline
\end{tabular}

Table 4. One-Sample Kolmogorov-Smirnov Test

\begin{tabular}{cccc}
\hline & $\mathrm{N}$ & $\begin{array}{c}\text { Kolmogorov- } \\
\text { Smirnov Z }\end{array}$ & $\begin{array}{c}\text { Asymp+ Sig. } \\
\text { (2-tailed) }\end{array}$ \\
\hline Learning & 47 & .72 & .67 \\
\hline $\begin{array}{c}\text { Interest in attending } \\
\text { educational environment }\end{array}$ & 47 & .88 & .41 \\
\hline
\end{tabular}


Table 5. The Independent Samples Test for Amount of Learning

\begin{tabular}{|c|c|c|c|c|c|c|c|}
\hline & \multirow[b]{2}{*}{ School } & \multirow[b]{2}{*}{$\mathrm{N}$} & \multirow[b]{2}{*}{ Mean } & \multirow{2}{*}{$\begin{array}{c}\text { Std. } \\
\text { Deviation }\end{array}$} & \multicolumn{3}{|c|}{ t-test for Equality of Means } \\
\hline & & & & & $\mathrm{T}$ & $\mathrm{df}$ & $\begin{array}{c}\text { Sig. } \\
\text { (2-tailed) }\end{array}$ \\
\hline \multirow{2}{*}{ Learning } & $\begin{array}{l}\text { Non-E } \\
\text { learning }\end{array}$ & 21 & 3.74 & .55 & \multirow{2}{*}{-2.92} & \multirow{2}{*}{45} & \multirow{2}{*}{.005} \\
\hline & E-Learning & 26 & 4.14 & .41 & & & \\
\hline
\end{tabular}

\section{Table 6. The Independent Samples t-Test for Degree of Interest in school attendance}

\begin{tabular}{|c|c|c|c|c|c|c|c|}
\hline & \multirow{2}{*}{ School } & \multirow[b]{2}{*}{$\mathrm{N}$} & \multirow[b]{2}{*}{ Mean } & \multirow{2}{*}{$\begin{array}{c}\text { Std. } \\
\text { Deviation }\end{array}$} & \multicolumn{3}{|c|}{ t-test for Equality of Means } \\
\hline & & & & & $\mathrm{t}$ & Df & $\begin{array}{c}\text { Sig. } \\
\text { (2-tailed) }\end{array}$ \\
\hline \multirow{2}{*}{$\begin{array}{c}\text { Interest } \\
\text { in school } \\
\text { attendance }\end{array}$} & $\begin{array}{c}\text { Non E } \\
\text { Learning }\end{array}$ & 21 & 3.79 & .64 & \multirow{2}{*}{-2.44} & \multirow{2}{*}{45} & \multirow{2}{*}{.019} \\
\hline & E-learning & 26 & 4.26 & .69 & & & \\
\hline
\end{tabular}

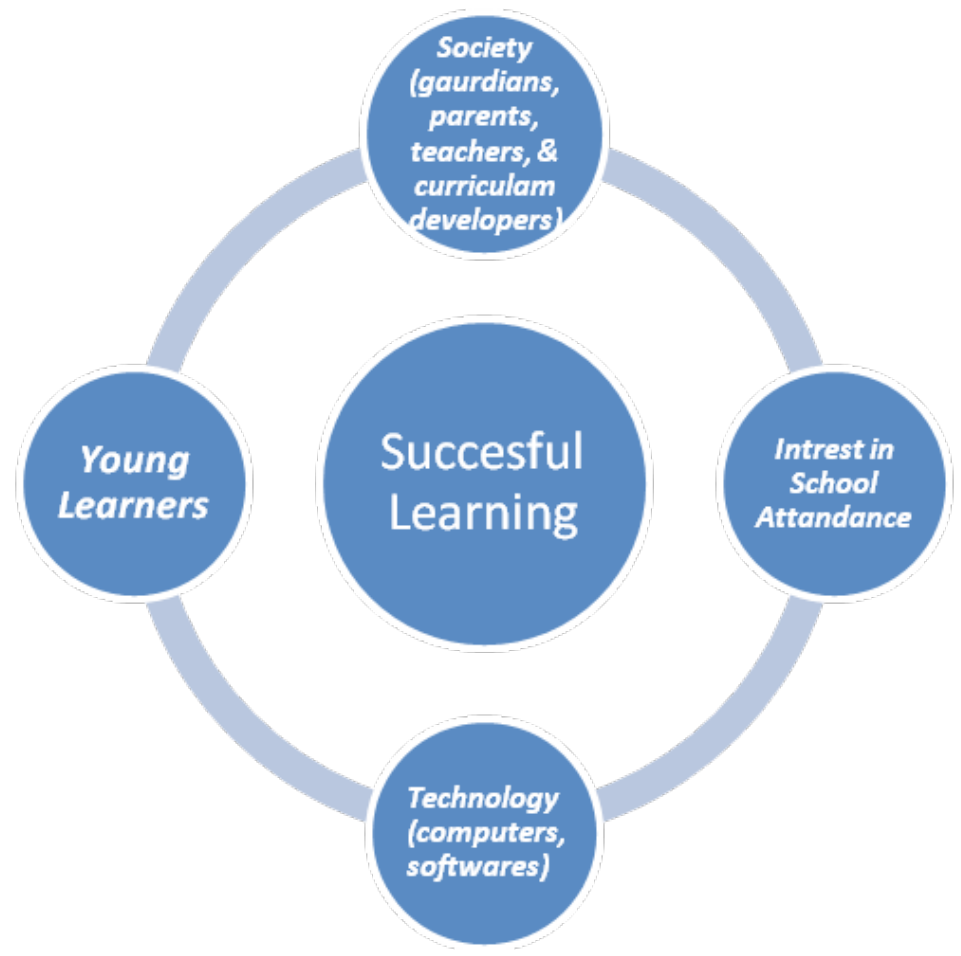

Figure 1. The intricate cycle of successful learning. 


\section{Conclusions}

The current research analyzed the effect of technology on the level of interest in school attendance and learning in young ages. Furthermore, the current study tried to demonstrate that when E-Learning such as computers and other electronic devices are used with parental monitoring, interest in attending educational environments are amplified at a young age. In addition, the academic performances were not negatively impacted in E-leaning schools when compared with non-E learning schools. Thus it begs the questions as to why E-Learning is needed in schools if learning is not significantly impacted. As indicated above, the current study concluded that E-Learning does not have an influence on learning; however, it significantly impacts interest in school attendance. However, if there is no school attendance, there would not be any learning.

The pedagogical implications of the study are that guardians, teachers, educational practitioners and curriculum developers can use this information to encourage school attendance in young learners. Despite the fact that the study did not find a positive correlation between technology and learning, it is intuitive to think that school attendance alone would have an impact in learning. Thus the current research can reduce the anxiety of parents, that children can safely use technological devises to improve their learning with the support and guidance of teachers, educational practitioners and curriculum developers. So, it can enhance their interest in attending to school and achieve a successful learning. In addition, this research will significantly impact curriculum developer's ability to design a more practical, technology based educational plan that fosters more independent learning with less reliance on educators. This can be accomplished by having a designated section for technology in education and its use in curriculum development.

\section{ACKNOWLEDGEMENT}

The authors would like to thank Doctor Arash Hassantoufighi for his support during the preparation of this manuscript. The authors would also appreciate Dr.Majid Vahedi for his invaluable mentorship during the preparation of this manuscript.

\section{References}

Alismail, HA. \& McGuire, P. 2015.21st Century Standards and Curriculum: Current Research and Practice. Journal of Education and Practice 6(6): 150-155.

Bork, A. 1985. Personal computers for education. New York: Harper \& Row. 
Bulut, O. \& E. Delen. 2011. "The relationship between students' exposure to technology, and their achievement in science and math." The Turkish Online Journal of Educational Technology 10(3): 311-317.

Chomsky, N. 2014. Noam Chomsky on Technology and Learning. Retrieved from http:// learning-reimagined.com.

Christen, A. 2009."Transforming the classroom for collaborative learning in the 21st century." Techniques: Connecting Education and Careers 84(1):28-31.

DePasquale, R., E. McNamara, \& K.Murphy.2003.“Meaningful connections: Using technology in primary classrooms." Young Children on the Web. Retrieved from http://journal.naeyc. org/btj/200311/techinprimaryclassrooms.pdf.

Ebrecht, B. \& H. Yu Ku. 2015. "A Case Study of Classroom Blogging in Three Elementary Schools." Journal of Educational Research and Innovation 4(1):3-19.

Hansen, C. C. 2008. "Observing technology enhanced literacy learning." Contemporary Issues in Technology and Teacher Education 8(2): 108-121. Retrieved from http://www. citejournal. org/vol8/iss2/languagearts/article.cfm

Howland, J. L., D. Jonassen, \& R. M. Marra 2012. Meaningful learning with technology. Boston: Pearson Education Inc.

Jacobsen,M.2001."Building different bridges: Technology integration, engaged student learning, and new approaches to professional development." Educational Research Association, Seattle, WA, 1(3), 29. Retrieved from http://www.eric.ed.gov/contentdelivery/servlet/ ERICServlet?accno=ED453232.

Kanuka, H., L. Rourke, \& E. Laflamme. 2007."The influence of instructional methods on the quality of online discussion." British Journal of Educational Technology 38(2): 260-271. doi: 10.1111/j.1467-8535.2006.00620.x.

Kurt, S. 2010."Technology use in elementary education in Turkeyः A case study." New Horizons in Education 58(1): 65-76.

Miller, S. 2011."Student voices for change." Learning and Leading with Technology 38(8):20-23.

Mueller, J. 2006. Authentic assessment toolbox. Retrieved from Journal of Online Learning and Teaching website: http://jonathan.mueller.faculty.noctrl.edu/toolbox/whatisit. htm\#looklike.

Nazarlou, M. 2013. "Research on Negative Effect on E-Learning." International Journal of Mobile Network Communications E Telematics (IJMNCT), 3(2).

Shafiei, S. \& M. Zoghi. 2014، "The Familiarity of EFL Teachers With Pos-Method: Considering Their Attitudes Towards Methods and Post-Method." International Journal of Language Learning and Applied Linguistics World 7(4): 145-156.

Solomon, G., \& L. Schrum. 2007. Web 2.0: New tools, new schools. Eugene, OR: International Society for Technology in Education. 